\title{
DUALIDADE DE PODERES NO ALVORECER DO BRASIL CONSTITUCIONAL (1821 A 1824)
}

\section{DUAL POWER AT THE DOWN OF THE CONSTITUTIONAL BRAZIL (1821 TO 1824)}

\author{
Marcio Ortiz Meinberg \\ Pontifícia Universidade Católica de São Paulo (PUC-SP).
}

SUMÁRIO: I. INTRODUÇÃO - II. AS CORTES DE LISBOA - III. O PRÍNCIPE REGENTE - IV. A INDEPENDÊNCIA DO BRASIL - V. A ASSEMBLEIA GERAL CONSTITUINTE E LEGISLATIVA - VI. CONCLUSÃO - VII. REFERENCIAS BIBLIOGRÁFICAS

Resumo: Trata-se de artigo cujo objetivo é traçar brevemente a história do processo que culminou na outorga da primeira Constituição Brasileira, para evidenciar a dualidade entre os Poderes que lutavam pela hegemonia política e jurídica no Brasil de 1821 até 1824. O período temporal selecionado inicia-se com a instituição das Cortes Gerais e Extraordinárias da Nação Portuguesa "Cortes Portuguesas" ou "Cortes de Lisboa") em 1821 e encerra-se com a outorga da "Constituição Política do Império do Brasil" por Dom Pedro I em 1824. Tal dualidade se manifestou em dois momentos distintos, sendo que: no primeiro momento a disputa ocorreu entre o Príncipe Dom Pedro (herdeiro da Coroa de Portugal, que era regente do Brasil) e as Cortes Portuguesas; e no segundo momento a disputa foi entre o Imperador Dom Pedro I e a Assembleia Geral Constituinte e Legislativa do Brasil. O trabalho utilizou o método histórico, reconstruindo a história do período selecionado a partir da análise de documentos legislativos da época, fazendo ao final do artigo uma síntese conclusiva e opinativa.

Abstract: This article objective is to briefly outline the history of the process that culminated in the granting of the first Brazilian Constitution, highlighting the dual power between the Powers that fought for the political and juridical hegemony in Brazil from 1821 to 1824 . The selected period starts with the inauguration of the General and Extraordinary Courts of the Portuguese Nation ("Portuguese Courts" or "Courts from Lisbon") in 1821 and ends with the granting of the "Political Constitution of the Empire of Brazil" by Dom Pedro I in 1824. The dual power is presented in two distinct moments: in the first moment the dispute was between the Prince Dom Pedro (heir to the Crown of Portugal, who was regent of Brazil) and the Portuguese Courts; and, in the second moment, the dispute was between the Emperor Dom Pedro I and the Constituent and Legislative General Assembly of Brazil. The study was performed according the historical method, by the reconstruction of the history of the selected period thru the analysis of the legislative documents of that time, and finishes with a conclusive and opinionated synthesis. 
Palavras-chave: HISTÓRIA CONSTITUCIONAL; CONSTITUIÇÃO DE 1824; INDEPENDÊNCIA DO BRASIL; DUALIDADE DE PODERES.

Keywords: CONSTITUTIONAL HISTORY; CONSTITUTION OF 1824; INDEPENDENCE OF BRAZIL; DUAL POWER.

\section{INTRODUÇÃO}

Com a aprovação da Constituição Política do Império do Brasil em 25 de março de 1824, outorgada pelo Imperador Dom Pedro I, iniciou-se a História Constitucional Brasileira. Não se tratou de um processo pacífico, muito pelo contrário, foi resultado de muitos enfrentamentos, no final vencidos por Dom Pedro I.

Em um primeiro momento, o ainda Príncipe Regente de Portugal digladiouse contra as Cortes de Lisboa, no movimento que levou à Independência do Brasil. No segundo momento, o já Imperador Dom Pedro I impôs-se à Assembleia Geral Constituinte e Legislativa liderada pelos irmãos Andrada (seus ex-aliados) e fez valer sua vontade. Durante ambos os períodos, houve dualidades de poderes, ou seja, a coexistência de dois polos de poder político antagônicos, que disputavam a legitimidade institucional e a hegemonia jurídica: Dom Pedro $\mathrm{x}$ Cortes de Lisboa ( $1^{\circ}$ momento); e Dom Pedro x Assembleia Geral Constituinte e Legislativa ( $2^{\circ}$ momento).

Tais disputas refletiram-se diretamente no direito positivo da época e ficaram registradas em compilados de legislação do Brasil e de Portugal. Através do Método Histórico, buscaremos, a partir da análise destes normativos jurídicos, reconstruir a história do processo que levou à ruptura entre Brasil e Portugal, e culminou na primeira Constituição Brasileira (foram selecionados os documentos que melhor revelam a disputa entre os poderes, dispensando decisões meramente administrativas, ainda que tivesse relevância política para outros temas). Alguns fatos políticos essenciais e eventuais lacunas históricas, que não puderam ser preenchidas por meio dos documentos legislativos, foram complementados a partir de textos doutrinários, mas demos prioridade para obras jurídicas de História Constitucional (em detrimento da História Geral).

Os quatro capítulos seguintes a esta Introdução (capítulos 2, 3, 4 e 5) são basicamente descritivos, ainda que com alguma contextualização nossa ou dos autores. Por fim, no capítulo 6 nos dedicaremos a apresentar uma breve síntese de todo o processo, dando enfoque para os aspectos relacionados à dualidade de poderes.

\section{Uma Dificuldade Metodológica}

Os documentos legislativos utilizados como base deste artigo refletem claramente a luta política entre as instituições que resultou em uma dualidade de poderes, o que dificultou a elaboração de algumas referências normativas. Segundo a Associação Brasileira de Normas Técnicas - $\mathrm{ABNT}^{1}$, a referência à

1 NBR 6023:2002, Informação e documentação - Referências - Elaboração. 
legislação deve ser estruturada da seguinte forma: jurisdição (entidade), título, numeração, data e dados da publicação, podendo em seguida ser acrescentados elementos complementares para facilitar a identificação do documento.

Ocorre que o Rei Dom João VI reconhecia a legitimidade das Cortes de Lisboa, de modo que as normas emitidas por estas eram reconhecidas não apenas em Portugal, mas também no restante do Império Português (inclusive no Brasil): por conta disso, as normas das Cortes são inicialmente referenciadas como tendo jurisdição sobre o REINO UNIDO DE PORTUGAL, BRASIL E ALGARVES.

Por outro lado, as Cortes não aceitavam que as normas emitidas pelo Rei a partir do Brasil vigorassem em Portugal (elas consideravam-se no exercício da regência em Portugal), de modo que as normas do Rei eram aceitas apenas no Brasil (assim como, posteriormente, as normas emitidas pelo Príncipe Regente): deste modo, as normas do Rei no Brasil (e depois as do Príncipe Regente) são referenciadas como tendo jurisdição apenas sobre o BRASIL (antes da Revolução do Porto estabelecer a "Regência do Reino", as normas do Rei tinham jurisdição sobre todo o Reino Unido).

Conforme a crise entre Dom Pedro e as Cortes evoluiu, cada um deles deixou de reconhecer a legitimidade do outro, porém, ao mesmo tempo em que as Cortes não puderam se impor ao Brasil, o Príncipe não se impôs a Portugal: assim, a partir da ruptura, as normas das Cortes são referenciadas apenas como tendo jurisdição sobre PORTUGAL (exceto aquelas que a Assembleia Geral Constituinte e Legislativa brasileira veio posteriormente reconhecer como válidas).

Por fim, como os normativos não eram numerados à época, optamos por incluir a ementa de cada um deles para facilitar a identificação (entre aspas ao final da referência).

\section{AS CORTES DE LISBOA}

Sob o aspecto jurídico, o Brasil somente surgiu como um novo Estado², totalmente separado de Portugal, a partir da Independência do Brasil oficializada em 7 de setembro de 1822. Este processo teve por antecedentes imediatos a criação da primeira Constituição do Reino de Portugal, Estado ao qual o Brasil estava vinculado, primeiro como colônia e desde 1815 como reino unido ${ }^{3}$.

2 Antes de 1500, havia um território sem Estado. A partir da conquista do território brasileiro por Portugal, surgiu uma colônia, cuja estrutura era indivisível do Estado da metrópole. Com a vinda da família real para o Brasil em 1808, as estruturas estatais passaram a tomar forma, mas ainda misturadas às do Estado Português. Em 1815, o Príncipe-Regente Dom João (futuro Dom João VI) elevou o Brasil à condição de "reino unido" a Portugal e Algarves, mas, ainda que tivesse obtido o "status" de reino, todas as estruturas estatais continuavam entrelaçadas e misturadas às portuguesas. Somente com a Independência em 1822 que, efetivamente, surgiu o Estado Brasileiro.

3 REINO UNIDO DE PORTUGAL, BRASIL E ALGARVES (Principe Regente do Reino Unido de Portugal, Brasil 1 e Algarves). Carta de Lei, de 16/12/1815. Eleva o Estado do Brasil à gradação e categoria de Reino. In REINO UNIDO DE PORTUGAL, BRASIL E ALGARVES, Collecção das Leis do Brazil de 1815. Parte 1 (Cartas de Lei, Alvarás, Decretos e Cartas Régias), Rio de Janeiro, Imprensa Nacional, 1890. Disponivel em 
Antes de 1822, o Reino Unido de Portugal, Brasil e Algarves não possuía uma Constituição e, em última instância, o poder do rei poderia ser considerado absoluto, uma vez que sequer existia um parlamento no sentido moderno do termo. O primeiro processo constituinte português iniciou-se com a Revolução Liberal do Porto em 1820, que em 24 de Janeiro de 1821 instituiu as Cortes Gerais e Extraordinárias da Nação Portuguesa (também conhecidas como Cortes Portuguesas ou Cortes de Lisboa), com a finalidade de atuar como parlamento soberano e elaborar a primeira Constituição do reino (o que incluía o Brasil).

As tentativas das Cortes Portuguesas de limitar os poderes absolutos da monarquia, e as do Rei de Portugal, Dom João VI, de manter tais poderes, colocaram em choque as duas instituições.

A partir de fevereiro de 1821, Dom João VI, temendo ser destronado pelas Cortes Portuguesas, deu as mais diversas demonstrações de apoio e fidelidade aos trabalhos da Constituinte, mas sempre de maneira contraditória. Inicialmente o Rei declarou que enviaria o Príncipe Dom Pedro, juntamente com procuradores brasileiros, para conhecer a Constituição em elaboração e avaliar a conveniência de sua adoção no Brasil (dando a entender que a Constituição elaborada pelas Cortes Portuguesas não seria necessariamente aplicada ao Brasil) 4 . Pouco depois Dom João VI recuou e logo declarou apoiar a "Constituição que se está fazendo em Portugal, recebendo-a no Reino do Brasil e mais domínios", que foi jurada pelo Príncipe Real em nome do Rei e em nome próprio 5 .

Em março de 1821 Dom João VI começou a organizar seu regresso à Portugal, enquanto tomou duas medidas preparatórias: indicou que o Príncipe

http://www2.camara.leg.br/atividade-legislativa/legislacao/publicacoes/doimperio. em 09/01/2018.

4 BRASIL (Rei do Reino Unido de Portugal, Brasil e Algarves). Decreto, de 18/02/1821. Determina que o Principe Real vá a Portugal; Convoca os Procuradores das Cidades e Vilas do Brasil para em junta de Cortes se tratar das Leis Constitucionais e cria uma comissão encarregada de preparar os trabalhos que se devem ocupar os mesmos procuradores. In BRASIL, Collecção das Leis do Brazil de 1821. Parte 2 (Decretos, Cartas e Alvarás), Rio de Janeiro, Imprensa Nacional, 1889. Disponivel em

http://www2.camara.leg.br/atividade-legislativa/legislacao/publicacoes/doimperio. Acesso em 09/01/2018.

BRASIL (Rei do Reino Unido de Portugal, Brasil e Algarves). Decreto, de 23/02/1821. Nomeia os membros da comissão encarregada de preparar as Leis Constitucionais. In BRASIL, Collecção das Leis do Brazil de 1821. Parte 2 (Decretos, Cartas e Alvarás), op. cit.

5 BRASIL (Rei do Reino Unido de Portugal, Brasil e Algarves). Decreto, de 24/02/1821 . Aprova a Constituição, que se está fazendo em Portugal, recendendo-a ao Reino do Brasil e mais dominios. In BRASIL, Collecção das Leis do Brazil de 1821. Parte 2 (Decretos, Cartas e Alvarás), op. cit..

BRASIL (Rei do Reino Unido de Portugal, Brasil e Algarves). Termo de Vereação do Senado da Câmara do Rio de Janeiro, de 26/02/1821. Auto de juramento prestado por El-Rei, Príncipes e mais pessoas, à Constituição que se está fazendo em Portugal pelas Cortes. In BRASIL, Collecção das Leis do Brazil de 1821. Parte 2 (Decretos, Cartas e Alvarás), Rio de Janeiro, Imprensa Nacional, 1889. Disponivel em

http://www2.camara.leg.br/atividade-legislativa/legislacao/publicacoes/doimperio. Acesso em 09/01/2018. 
Dom Pedro ficaria no Brasil, encarregado de estabelecer um governo provisório6; e determinou a eleição de deputados constituintes brasileiros, que deveriam acompanhar o Rei em seu retorno (a eleição seria realizada conforme o método estabelecido pela Constituição Espanhola de Cádiz, o mesmo utilizado para a eleição dos deputados das Cortes de Lisboa) ${ }^{7}$.

Enquanto isso, em Portugal, no dia 10 de março de 1821, as Cortes instituíram as "Bases da Constituição Política da Monarquia Portuguesa" (um documento progressista, que estabelecia os Direitos Fundamentais dos cidadãos, previa a Separação dos Poderes e organizava o funcionamento do Estado) ${ }^{8}$. Em tese, o documento "Bases da Constituição" pode ser considerado o primeiro documento com fundamentos constitucionais que vigorou em Portugal, quase uma "pré-constituição".

Na noite de 21 de abril de 1821, no Brasil, ocorreu um fato no mínimo curioso. Os eleitores reunidos na Praça do Comércio para escolher os deputados constituintes brasileiros junto às Cortes decidiram reivindicar ao Rei que adotasse no Brasil a Constituição Espanhola de 1812 (Constituição de Cádiz) enquanto não fosse finalizada a Constituição deliberada em Portugal. Pressionado pela comissão que se dirigiu ao palácio, Dom João VI, por meio de um decreto ${ }^{9}$, colocou em vigor, no Brasil, a Constituição Espanhola de Cádiz (temporariamente, enquanto não se concluísse a Constituição em elaboração pelas Cortes de Lisboa).

Ocorre que, logo no dia seguinte, o Rei voltou atrás em sua decisão e revogou o decreto do dia anterior, acusando a comissão que o havia convencido de ser composta "por homens mal intencionados"10, ordenando a abertura de uma investigação contra "os perversos sediciosos e amotinadores"11, o que resultou em

6 BRASIL (Rei do Reino Unido de Portugal, Brasil e Algarves). Decreto, de 07/03/1821. Trata do regresso d'El-Rei para Lisboa, ficando o Príncipe Real encarregado do Governo Provisório do Brasil. In BRASIL, Collecção das Leis do Brazil de 1821. Parte 2 (Decretos, Cartas e Alvarás), op. cit..

7 BRASIL (Rei do Reino Unido de Portugal, Brasil e Algarves). Decreto, de 07/03/1821. Manda proceder à nomeação dos Deputados às Cortes Portuguesas, dando instruções a respeito. In BRASIL, Collecção das Leis do Brazil de 1821. Parte 2 (Decretos, Cartas e Alvarás), op. cit..

8 REINO UNIDO DE PORTUGAL, BRASIL E ALGARVES (Cortes Gerais). Decreto, de 10/03/1821. Dá as Bases da Constituição Política da Monarquia Portuguesa. In REINO UNIDO DE PORTUGAL, BRASIL E ALGARVES, Collecção das Leis do Brazil de 1821. Parte 1 (Leis das Cortes Geraes Extraordinárias e Constituintes da Nação Portugueza), Rio de Janeiro, Imprensa Nacional, 1889. Disponivel em

http://www2.camara.leg.br/atividade-legislativa/legislacao/publicacoes/doimperio. Acesso em 09/01/2018.

9 BRASIL (Rei do Reino Unido de Portugal, Brasil e Algarves). Decreto, de 21/04/1821. Manda adotar a Constituição Espanhola, enquanto não vigora a nova encarregada às Cortes de Lisboa. In BRASIL, Collecção das Leis do Brazil de 1821. Parte 2 (Decretos, Cartas e Alvarás), op. cit.

10 BRASIL (Rei do Reino Unido de Portugal, Brasil e Algarves). Decreto, de 22/04/1821. Anula o Decreto datado de ontem que mandou adotar no Reino do Brasil a Constituição Espanhola. In BRASIL, Collecção das Leis do Brazil de 1821. Parte 2 (Decretos, Cartas e Alvarás), op. cit.

11 BRASIL (Rei do Reino Unido de Portugal, Brasil e Algarves). Decreto, de 22/04/1821. Manda proceder a devassa contra os sediciosos e amotinadores da Praça do Comércio do Rio de Janeiro 
uma violenta repressão das tropas aos cidadãos que estavam na Praça do Comércio, no episódio que viria a ser conhecido como "O açougue de Bragança" 12 . Sendo assim, é possivel afirmar que a primeira Constituição em vigor no território brasileiro, ainda que por menos de 24 horas, foi a Constituição Espanhola de Cádiz de 1812. Apesar da situação inusitada e de pouco tempo em vigor, a Constituição Espanhola de Cádiz de 1812 é considerada a principal inspiração para as Cortes Portuguesas e para a Constituição Portuguesa de $1822^{13}$.

\section{O PRÍNCIPE REGENTE}

Finalmente, em 25 de abril de 1821, Dom João VI partiu com a corte de volta para Lisboa, sendo que, a partir desta data, o exercício direto do governo do Brasil passou a ser realizado pelo então Príncipe Regente ${ }^{14}$. Assim, a partir de 26 de abril de 1821 passou a existir uma dualidade de poderes entre Brasil e Portugal e, consequentemente, uma sobreposição de sistemas jurídicos (que se enfrentariam, primeiro silenciosamente, e depois em confronto aberto, até resultar em ruptura definitiva com a proclamação da Independência do Brasil).

Apesar de tal dualidade, fica evidente que tanto as Cortes em Portugal, como o Príncipe Regente Dom Pedro no Brasil, tinham indole liberal, o que pode ser atestado pelo teor de diversas normas instituídas por cada um deles. As Cortes conclamaram todos os estados portugueses do ultramar a eleger seus representantes para a Constituinte ${ }^{15}$, estabeleceram a liberdade de ensino ${ }^{16}$, regulamentaram a liberdade de imprensa ${ }^{17}$ e estabeleceram a inviolabilidade de

do dia 21 deste mês. In BRASIL, Collecção das Leis do Brazil de 1821. Parte 2 (Decretos, Cartas e Alvarás), op. cit.

12 Vicente de Paulo BARRETTO e Vitor Pimentel PEREIRA, “¡Viva la Pepa!: A História não Contada da Constituición Española de 1812 em Terras Brasileiras”, In R IHGB, Rio de Janeiro, a.173 (452), jul./set, 2011, pp. 201-223. Disponivel em https://ihgb.org.br/revistaeletronica/artigos-452/item/108334-viva-la-pepa-a-historia-nao-contada-da-constitucionespanola-de-1812-em-terras-brasileiras.html. Acesso em 19/02/2018.

13 Helga Maria Saboia BEZERRA, “A Constituição da Cádiz de 1812”, In Revista de Informação Legislativa, ano 50, n. 198, abr./jun. 2013, pp. 89-112. Disponivel em https://www12.senado.leg.br/ril/edicoes/50/198/ril_v50_n198_p89.pdf. Acesso em $12 / 01 / 2018$.

14 BRASIL (Rei do Reino Unido de Portugal, Brasil e Algarves). Decreto, de 22/04/1821. Encarrega o Governo Geral do Brasil ao Príncipe Real constituído Regente e Lugar-Tenente d'ElRei. In BRASIL, Collecção das Leis do Brazil de 1821. Parte 2 (Decretos, Cartas e Alvarás), op. cit.

15 REINO UNIDO DE PORTUGAL, BRASIL E ALGARVES (Cortes Gerais). Decreto, de 24/04/1821. Declara legítimos os Governos Estabelecidos ou que se estabelecerem nos Estados Portugueses de Ultramar, para abraçarem a causa da regeneração política. In REINO UNIDO DE PORTUGAL, BRASIL E ALGARVES, Collecção das Leis do Brazil de 1821. Parte 1 (Leis das Cortes Geraes Extraordinárias e Constituintes da Nação Portugueza), op. cit.

16 REINO UNIDO DE PORTUGAL, BRASIL E ALGARVES (Cortes Gerais). Decreto, de 30/06/1821. Permite a qualquer cidadão o ensino, e abertura de escola de primeiras letras, independente de exame ou licença. In REINO UNIDO DE PORTUGAL, BRASIL E ALGARVES, Collecção das Leis do Brazil de 1821. Parte 1 (Leis das Cortes Geraes Extraordinárias e Constituintes da Nação Portugueza), op. cit.

17 REINO UNIDO DE PORTUGAL, BRASIL E ALGARVES (Cortes Gerais). Decreto, de 12/07/1821. Desenvolve e determina os principios que sobre a liberdade de imprensa se acham estabelecidos nos arts. $8^{\circ}, 9^{\circ}$ e 10 das Bases da Constituição. In REINO UNIDO DE PORTUGAL, 
domicílio $^{18}$ (curiosamente, esta ultima lei foi proclamada pelas Cortes em 14 de outubro de 1822, ou seja, após a Independência do Brasil, mas mesmo assim foi posteriormente reconhecida como válida no Brasil). Por sua vez, Dom Pedro, enquanto Príncipe Regente, reconheceu o direito à propriedade (proibindo o confisco de bens sem indenização) ${ }^{19}$ e deu providências para garantia das liberdades individuais ${ }^{20}$ (mais tarde, como Imperador, estabeleceria diversas normas para regulamentar a liberdade de imprensa ${ }^{21}$ ).

Em 03 de julho de 1821, Dom João VI chegou à Lisboa e jurou solenemente obedecer às Bases da Constituição Politica da Monarquia Portuguesa. No Brasil, o Príncipe Regente Dom Pedro já tinha se antecipado e, quase um mês antes, já havia jurado e mandado jurar e aplicar as Bases da Constituição em todo território brasileiro ${ }^{22}$.

Apesar das Cortes Portuguesas e do Príncipe Regente Dom Pedro ambos possuírem índole liberal, em pouco tempo já entrariam em conflito. Entre setembro e outubro de 1821, as Cortes passaram a decretar normas de organização dos governos das províncias brasileiras ${ }^{23}$ e determinaram o retorno

BRASIL E ALGARVES, Collecção das Leis do Brazil de 1821. Parte 1 (Leis das Cortes Geraes Extraordinárias e Constituintes da Nação Portugueza), op. cit.

18 REINO UNIDO DE PORTUGAL, BRASIL E ALGARVES (Cortes Gerais). Lei, de 14/10/1822. Combina o respeito devido à casa do Cidadão com a administração da Justiça. In REINO UNIDO DE PORTUGAL, BRASIL E ALGARVES, Collecção das Leis do Brazil de 1821. Parte 1 (Leis das Cortes Geraes Extraordinárias e Constituintes da Nação Portugueza), op. cit.

19 BRASIL (Principe Regente). Decreto, de 21/05/1821. Proíbe tomar-se a qualquer coisa contra a sua vontade, e sem indenização. In BRASIL, Collecção das Leis do Brazil de 1821. Parte 2 (Decretos, Cartas e Alvarás), op. cit..

20 BRASIL (Príncipe Regente). Decreto, de 23/05/1821. Dá providências para garantia da liberdade individual. In BRASIL, Collecção das Leis do Brazil de 1821. Parte 2 (Decretos, Cartas e Alvarás), op. cit..

21 BRASIL (Principe Regente). Decreto, de 18/06/1822. Cria Juízes de Fato para julgamento dos crimes de abuso de liberdade de imprensa. In BRASIL, Collecção das Leis do Império do Brazil de 1822. Parte 2 (Decretos, Cartas e Alvarás), Rio de Janeiro, Imprensa Nacional, 1887. Disponivel em http://www2.camara.leg.br/atividade-legislativa/legislacao/publicacoes/doimperio. Acesso em 09/01/2018.

BRASIL (Príncipe Regente). Decreto, de 22/11/1823. Manda executar provisoriamente o projeto de lei da Assembleia Constituinte sobre liberdade de imprensa. In BRASIL, Collecção das Leis do Império do Brazil de 1823. Parte 2 (Decretos, Cartas e Alvarás), Rio de Janeiro, Imprensa Nacional, 1887. Disponivel em

http://www2.camara.leg.br/atividade-legislativa/legislacao/publicacoes/doimperio. Acesso em 09/01/2018.

BRASIL (Governo do Império). Portaria, de 23/07/1823. Solve dúvidas sobre acusação dos delitos cometidos por abuso da liberdade de imprensa. In BRASIL, Collecção das Decisões do Governo do Império do Brazil de 1823, Rio de Janeir,: Imprensa Nacional, 1887. Disponível em http://www2.camara.leg.br/atividade-legislativa/legislacao/publicacoes/doimperio. Acesso em $09 / 01 / 2018$.

22 BRASIL (Principe Regente). Decreto, de 08/06/1821. Manda prestar juramento às Bases da Constituição nas províncias do Reino do Brasil. In BRASIL, Collecção das Leis do Brazil de 1821. Parte 2 (Decretos, Cartas e Alvarás), op. cit..

23 REINO UNIDO DE PORTUGAL, BRASIL E ALGARVES (Cortes Gerais). Decreto, de $1^{\circ} / 09 / 1821$. Sobre a organização da Junta Provisória e Governo de Armas da Província de 
de Dom Pedro a Portugal, para que passasse a viajar incógnito pela Espanha, França e Inglaterra "a fim de obter aqueles conhecimentos que se fizerem necessários, para um dia ocupar dignamente o Trono Português"24.

Em 9 de janeiro de 1822, o Príncipe Regente suspendeu sua ida para Portugal, naquele que ficou conhecido como "Dia do Fico"25. Ainda não havia ali ruptura, tanto que, segundo o termo que registrou o feito, as "vivas" em resposta à decisão de Dom Pedro teriam sido: "Viva a Religião! Viva a Constituição! Vivam as Cortes! Viva El Rei Constitucional! Viva o Príncipe Constitucional! Viva a união de Portugal com o Brasil!".

Alguns dias depois o Príncipe Regente ainda recomendou "união e tranquilidade" ao povo e à tropa ${ }^{26}$. Apesar disso, Dom Pedro iniciou procedimentos de natureza militar e, naquela mesma data, unificou o comando de suas tropas (que desde o ano anterior eram comandadas por uma Comissão Militar colegiada ${ }^{27}$ e passaram ao comando unificado de um Governador de Armas da Corte e Província) ${ }^{28}$ e convocou ao Rio de Janeiro reforços vindos das províncias de São Paulo e Minas Gerais ${ }^{29}$. No âmbito administrativo, em 17 de

Pernambuco. In REINO UNIDO DE PORTUGAL, BRASIL E ALGARVES, Collecção das Leis do Brazil de 1821. Parte 1 (Leis das Cortes Geraes Extraordinárias e Constituintes da Nação Portugueza), op. cit.

REINO UNIDO DE PORTUGAL, BRASIL E ALGARVES (Cortes Gerais). Decreto, de 1\%/10/1821. Determina provisoriamente a forma da Administração Pública e Militar das Provincias do Brasil. In, REINO UNIDO DE PORTUGAL, BRASIL E ALGARVES, Collecção das Leis do Brazil de 1821. Parte 1 (Leis das Cortes Geraes Extraordinárias e Constituintes da Nação Portugueza), op. cit.

REINO UNIDO DE PORTUGAL, BRASIL E ALGARVES (Cortes Gerais). Lei, de18/01/1822. Extingue os Tribunais criados no Rio de Janeiro e estabelece a forma de Administração das Provincias do Brasil. In REINO UNIDO DE PORTUGAL, BRASIL E ALGARVES, Collecção das Leis do Império do Brazil de 1822. Parte 1 (Leis das Cortes Geraes Extraordinárias e Constituintes da Nação Portugueza), Rio de Janeiro, Imprensa Nacional, 1887. Disponível em http://www2.camara.leg.br/atividade-legislativa/legislacao/publicacoes/doimperio. Acesso em $09 / 01 / 2018$.

24 REINO UNIDO DE PORTUGAL, BRASIL E ALGARVES (Cortes Gerais). Decreto, de $1^{\circ} / 10 / 1821$. Determina a viagem do Príncipe Real por algumas cortes da Europa. In REINO UNIDO DE PORTUGAL, BRASIL E ALGARVES, Collecção das Leis do Brazil de 1821. Parte 1 (Leis das Cortes Geraes Extraordinárias e Constituintes da Nação Portugueza), op. cit.

25 BRASIL (Príncipe Regente). Termo de Vereação do Senado da Câmara do Rio de Janeiro, de 09/01/1822. O Príncipe Regente declara ficar no Brasil. In BRASIL, Collecção das Leis do Império do Brazil de 1822. Parte 2 (Decretos, Cartas e Alvarás), op. cit.

26 BRASIL (Príncipe Regente). Proclamação, de 12/01/1822. Recomenda união e tranquilidade. In BRASIL, Collecção das Leis do Império do Brazil de 1822. Parte 2 (Decretos, Cartas e Alvarás), op. cit.

27 BRASIL (Príncipe Regente). Decreto, de 06/06/1821. Cria uma Comissão Militar para exercer o Governo das Armas desta Corte e Província. In BRASIL, Collecção das Leis do Brazil de 1821. Parte 2 (Decretos, Cartas e Alvarás), op. cit.

28 BRASIL (Príncipe Regente). Decreto, de 12/01/1822. Extingue a Comissão Militar que exercia o Governo das Armas da Corte e Província. In BRASIL, Collecção das Leis do Império do Brazil de 1822. Parte 2 (Decretos, Cartas e Alvarás), op. cit.

${ }^{29}$ BRASIL (Príncipe Regente). Carta Régia, de 12/01/1822. Exige das Províncias de São Paulo e Minas Gerais a remessa de força armada, para guarnição desta cidade. In BRASIL, Collecção das Leis do Império do Brazil de 1822. Parte 2 (Decretos, Cartas e Alvarás), op. cit. 
janeiro de 1822 iniciaram-se as atividades do novo ministério, composto apenas por brasileiros e liderados por José Bonifácio de Andrada e Silva (o "Patriarca da Independência"), e, entre elas, a divulgação geral da decisão do Príncipe de ficar no Brasilio, a ordem para que todas as leis das Cortes Portuguesas fossem previamente submetidas ao conhecimento de Dom Pedro ${ }^{31}$ e a recomendação para que todos os governos das províncias se sujeitassem apenas à autoridade do Príncipe Regente ${ }^{32}$. Por fim, Dom Pedro criou o Conselho de Procuradores Gerais das Províncias do Brasil ${ }^{33}$, com representantes eleitos de cada província (mas sem poderes legislativos ${ }^{34}$ ).

Como reação à negativa de Dom Pedro em submeter-se às Cortes de Lisboa, algumas tropas portuguesas localizadas no Brasil (que compunham a chamada "Divisão Auxiliadora de Portugal") rebelaram-se contra o Príncipe Regente. Tratadas como rebeldes e insubordinadas, Dom Pedro determinou o embarque da Divisão Auxiliadora para fora território nacional ${ }^{35}$ e o governo brasileiro proibiu o desembarque de quaisquer outras tropas portuguesas que se dirigissem ao Brasil ${ }^{36}$.

A partir de maio de 1822, as tensões entre o Príncipe Regente e as Cortes Portuguesas se intensificaram, a ponto do governo brasileiro determinar que nenhum decreto das Cortes fosse aplicado sem receber o "cumpra-se" de Dom

30 BRASIL (Governo do Império). Portaria, de 17/01/1822. Dá conhecimento ao Governo das Províncias da deliberação do Príncipe Regente, de suspender a sua saída para Portugal. In BRASIL, Collecção das Decisões do Governo do Brazil de 1822, Rio de Janeiro, Imprensa Nacional, 1887. Disponivel em

http://www2.camara.leg.br/atividade-legislativa/legislacao/publicacoes/doimperio. Acesso em 09/01/2018.

31 BRASIL (Governo do Império). Portaria, de 21/01/1822. Manda submeter ao conhecimento de S.A. Real, o Principe Regente, as Leis das Cortes Portuguesas. In BRASIL, Collecção das Decisões do Governo do Brazil de 1822, op. cit.

32 BRASIL (Governo do Império). Portaria, de 30/01/1822. Recomenda aos Governos Provisórios que promovam a união de todas as Províncias com sujeição à Regência de S.A. Real. In BRASIL, Collecção das Decisões do Governo do Brazil de 1822, op. cit.

33 BRASIL (Principe Regente). Decreto, de 16/02/1822. Cria o Conselho de Procuradores Gerais das Províncias do Brasil. In BRASIL, Collecção das Leis do Império do Brazil de 1822. Parte 2 (Decretos, Cartas e Alvarás), op. cit.

34 BRASIL (Governo do Império). Portaria, de 27/05/1822. Explica o Decreto de 16 de fevereiro deste ano que criou um Conselho de Procuradores Gerais do Brasil. In BRASIL, Collecção das Decisões do Governo do Brazil de 1822, op. cit.

35 BRASIL (Príncipe Regente). Proclamação, de 02/02/1822. Trata da representação do General e Comandante dos Corpos da Divisão Auxiliadora do Exército de Portugal. In BRASIL, Collecção das Leis do Império do Brazil de 1822. Parte 2 (Decretos, Cartas e Alvarás), op. cit.

BRASIL (Príncipe Regente). Proclamação, de 17/02/1822. Sobre a insubordinação dos soldados portugueses. In BRASIL, Collecção das Leis do Império do Brazil de 1822. Parte 2 (Decretos, Cartas e Alvarás), op. cit.

36 BRASIL (Governo do Império). Portaria, de 17/02/1822. Manda proibir o desembarque de tropas que de Portugal se dirigirem a este país. In BRASIL, Collecção das Decisões do Governo do Brazil de 1822, op. cit. 
Pedro ${ }^{37}$. No dia 13 do mesmo mês, Dom Pedro aceitou o título de Defensor Perpétuo do Brasilis e, entre as "vivas" registradas no Termo de Vereação do Senado, não constou o "Viva a união de Portugal com o Brasil!" (as "Vivam as Cortes!" ainda estava lá, mas em uma posição de muito menos destaque).

A ausência da "Viva a união de Portugal com o Brasil!" não era ainda um rompimento, pois este reapareceu, dez dias depois, em outra aclamação ao Príncipe Regente: dessa vez pedindo a convocação de uma constituinte brasileira ${ }^{39}$. Em 02 de junho de 1822, reuniu-se o Conselho de Procuradores Gerais das Províncias do Brasil, que logo reivindicou também a convocação da constituinte $^{40}$. Enfim, em 03 de junho de 1822, Dom Pedro convocou uma Assembleia Geral Constituinte e Legislativa, ${ }^{41}$ visando a "integridade da Monarquia Portuguesa e o justo decoro do Brasil".

As normas eleitorais foram estabelecidas por José Bonifácio ${ }^{42}$ e previam o seguinte:

a) Teria direito a voto todo cidadão com mais de 20 anos (ou casados com idade inferior a esta) e que tivesse ao menos um ano de residência no local de voto, porém excluindo o voto dos que recebiam salários (com algumas exceções), religiosos, estrangeiros não-naturalizados e criminosos. Não era necessário ao eleitor ser alfabetizado;

b) As eleições seriam indiretas, sendo que cada freguesia deveria eleger "eleitores de paróquia", que, por sua vez, votariam nos candidatos a deputado constituinte;

c) O voto era múltiplo (quando havia mais de um eleitor a ser escolhido) e descoberto;

d) A quantidade de "eleitores de paróquia" era proporcional ao número de "fogos" (habitações familiares);

37 BRASIL (Governo do Império). Portaria, de 04/05/1822. Determina que não se dê execução a nenhum decreto das Cortes Portuguesas, sem que tenha o "cumpra-se" de Sua Alteza Real. In BRASIL, Collecção das Decisões do Governo do Brazil de 1822, op. cit.

38 BRASIL (Príncipe Regente). Termo de Vereação do Senado da Câmara do Rio de Janeiro, de 13/05/1822. O Príncipe Regente aceita o título de Defensor Perpétuo do Brasil. In BRASIL, Collecção das Leis do Império do Brazil de 1822. Parte 2 (Decretos, Cartas e Alvarás), op. cit.

39 BRASIL (Senado da Câmara do Rio de Janeiro). Termo de Vereação do Senado da Câmara do Rio de Janeiro, de 23/05/1822. O Senado da Câmara pede a Convocação de uma Assembleia Geral Constituinte no Brasil. In BRASIL, Collecção das Leis do Império do Brazil de 1822. Parte 2 (Decretos, Cartas e Alvarás), op. cit.

40 BRASIL (Conselho dos Procuradores Gerais). Requerimento dos Procuradores das Províncias e Ministros de Estado Pedindo a Convocação de Cortes no Brasil, de 03/07/1822. In BRASIL, Collecção das Leis do Império do Brazil de 1822. Parte 2 (Decretos, Cartas e Alvarás), op. cit. .

${ }^{41}$ BRASIL (Príncipe Regente). Decreto, de 03/06/1822. Manda convocar uma Assembleia Geral Constituinte e Legislativa composta de Deputados das Provincias do Brasil, os quais serão eleitos pelas instruções que forem expedidas. In BRASIL, Collecção das Leis do Império do Brazil de 1822. Parte 2 (Decretos, Cartas e Alvarás), op. cit.

42 BRASIL (Governo do Império). Portaria, de 19/06/1822. Instruções, a que se refere o Real Decreto de 3 de Junho do corrente ano que manda convocar uma Assembleia Geral Constituinte e Legislativa para o Reino do Brasil. In BRASIL, Collecção das Decisões do Governo do Brazil de 1822, op. cit. 
e) Provisoriamente foi estabelecido o número de 100 constituintes, distribuídos proporcionalmente às províncias conforme sua população;

f) Os requisitos para ser escolhido "eleitor de paróquia" eram: além dos requeridos para votar, estar domiciliado há quatro anos na província, bem como "ter mais de 25 anos de idade, ser homem probo e honrado, de bom entendimento, sem nenhuma sombra de suspeita e inimizade à causa do Brasil, e de decente subsistência por emprego, ou indústria ou bens"; e

g) Os requisitos para ser nomeado deputado, eram: além dos requeridos para ser "eleitor de paróquia" (exceto o domicílio, uma vez que poderiam ser eleitos por mais de uma província), ser natural do Brasil ou estrangeiro (da Monarquia Portuguesa ou naturalizado) com 12 anos de residência no Brasil e "que reúna a maior instrução, reconhecidas virtudes, verdadeiro patriotismo e decidido zelo pela causa do Brasil".

As Cortes de Lisboa não se quedaram inertes frente aos últimos atos de Dom Pedro e tentaram afastá-lo de suas funções como regente, determinando que ele permanecesse residindo no Rio de Janeiro enquanto seriam nomeados novos secretários para governar o Brasil ${ }^{43}$. Além disso, as Cortes mandaram cancelar a convocação do Conselho de Procuradores Gerais das Províncias do Brasil ${ }^{44}$ e processar os membros da Junta Provisional de São Paulo45. Posteriormente as Cortes anularam todos os atos praticados pelo Príncipe (que, segundo entendiam, não mais exercia a regência), determinaram o retorno de Dom Pedro à Portugal e declararam que todo comandante ou autoridade do governo brasileiro que não cumprisse tais determinações seria considerado traidor e criminoso ${ }^{46}$.

As hostilidades entre Dom Pedro e as Cortes Portuguesas se aguçaram, a ponto do Príncipe ordenar que o Governador de Armas da Bahia se recolhesse a Portugal com sua tropa ${ }^{47}$, bem como a Divisão de Voluntários Reais D’E1 Rei

43 PORTUGAL (Cortes Gerais). Decreto, de 27/07/1822. Determinar que o Príncipe continue a residir no Rio de Janeiro que se instalem Juntas Provisórias onde as não há. In PORTUGAL, Legislação Régia (Digitalização da Colecção de Legislação Portuguesa desde 1603 a 1910). Disponivel em http://legislacaoregia.parlamento.pt/Pesquisa/Default.aspx?ts=1. Acesso em $09 / 01 / 2018$.

44 PORTUGAL (Cortes Gerais). Decreto, de 30/07/1822. Declarar de nenhum efeito o Decreto dado no Rio do Janeiro a 16 de Fevereiro de 1822 em que o Governo convocava um Conselho de Procuradores das Províncias. In PORTUGAL, Legislação Régia (Digitalização da Colecção de Legislação Portuguesa desde 1603 a 1910), op. cit.

45 PORTUGAL (Cortes Gerais). Decreto, de 30/07/1822. Mandar que se processem alguns Membros da Junta Provisional de S. Paulo. In PORTUGAL, Legislação Régia (Digitalização da Colecção de Legislação Portuguesa desde 1603 a 1910), op. cit.

46 PORTUGAL (Cortes Gerais). Decreto, de 26/09/1822. Declarar nulos todos os atos legislativos emanados do Governo do Rio de Janeiro tomando diversas medidas sobre o mesmo Governo, Regência do Brasil, Príncipe Real, etc. In PORTUGAL, Legislação Régia (Digitalização da Colecção de Legislação Portuguesa desde 1603 a 1910), op. cit.

47 BRASIL (Príncipe Regente). Carta Régia, de 15/06/1822. Ordena ao Brigadeiro Ignácio Luiz Madeira de Mello, Governador de Armas da Bahia, que se recolha a Portugal com sua Tropa. In BRASIL, Collecção das Leis do Império do Brazil de 1822. Parte 2 (Decretos, Cartas e Alvarás), op. cit. 
(estacionada em Montevidéu, na Província Cisplatina) ${ }^{48}$. Eis que em agosto de 1822 explodiu finalmente a guerra ${ }^{49}$ e Dom Pedro declarou inimigas todas as tropas mandadas de Portugal ${ }^{50}$, e também ordenou que não fossem empossados quaisquer empregados que tenham vindo despachados de Portugal ${ }^{51}$. Ao mesmo tempo, enviou "Encarregados de Negócios" (embaixadores) para a Inglaterra, França e Estados Unidos ${ }^{52}$.

\section{A INDEPENDÊNCIA DO BRASIL}

Em 7 de setembro de 1822, com a Independência do Brasil, ocorreu a definitiva ruptura com Portugal, de modo que o Brasil passa a existir efetivamente como um novo Estado53. Desta forma, encerrou-se a sobreposição de sistemas jurídicos revelados na disputa entre o Principe-Regente e as Cortes de Lisboa. Posteriormente, a Assembleia Geral Constituinte e Legislativa do Brasil viria a regulamentar a validade das leis durante o periodo de dualidade (entre 25/04/1821 e 07/09/1822).

Dom Pedro I criou diversos símbolos nacionais brasileiros, que substituíram os portugueses (bandeira, escudo de armas, uniformes etc) ${ }^{54}$, até que em 12 de

48 BRASIL (Príncipe Regente). Decreto, de 20/07/1822. Manda regressar para Portugal a Divisão dos Voluntários Reais d'El-Rei estacionados em Montevidéu. In BRASIL, Collecção das Leis do Império do Brazil de 1822. Parte 2 (Decretos, Cartas e Alvarás), op. cit.

49 BRASIL (Príncipe Regente). Manifesto, de 1\%/08/1822. Esclarece os Povos do Brasil das causas da guerra travada contra o Governo de Portugal. In BRASIL, Collecção das Leis do Império do Brazil de 1822. Parte 2 (Decretos, Cartas e Alvarás), op. cit.

BRASIL (Príncipe Regente). Manifesto, de 06/08/1822. Sobre as relações politicas e comerciais com os governos e nações amigas. In BRASIL, Collecção das Leis do Império do Brazil de 1822. Parte 2 (Decretos, Cartas e Alvarás), op. cit.

50 BRASIL (Principe Regente). Decreto, de $1^{\circ} / 08 / 1822$. Declara inimigas as Tropas mandadas de Portugal. In BRASIL, Collecção das Leis do Império do Brazil de 1822. Parte 2 (Decretos, Cartas e Alvarás), op. cit.

51 BRASIL (Governo do Império). Portaria, de 05/08/1822. Ordena aos Governos Provisórios das Províncias que não deem posse a empregados que vierem despachados de Portugal. In BRASIL, Collecção das Leis do Império do Brazil de 1822. Parte 2 (Decretos, Cartas e Alvarás), op. cit.

52 BRASIL (Governo do Império). Portaria, de $1^{\circ} / 09 / 1822$. Comunica a nomeação de Encarregados de Negócios junto aos Governos de Inglaterra, França e Estados-Unidos. In BRASIL, Collecção das Decisões do Governo do Brazil de 1822, op. cit.

53 BRASIL (Príncipe Regente). Proclamação, 08/09/1822. Sobre a divisa do Brasil Independência ou Morte. In BRASIL, Collecção das Leis do Império do Brazil de 1822. Parte 2 (Decretos, Cartas e Alvarás), op. cit.

54 BRASIL (Príncipe Regente). Decreto, de 18/09/1822. Concede anistia geral para as passadas opiniões políticas; ordena o distintivo - Independência ou Morte - e a saída dos dissidentes. In BRASIL, Collecção das Leis do Império do Brazil de 1822. Parte 2 (Decretos, Cartas e Alvarás), op. cit.

BRASIL (Principe Regente). Decreto, de 18/09/1822. Determina o topo nacional Braziliense, e a legenda dos patriotas do Brasil. In BRASIL, Collecção das Leis do Império do Brazil de 1822. Parte 2 (Decretos, Cartas e Alvarás), op. cit. 
outubro foi aclamado Imperador Constitucional do Brasil55 (antes desta aclamação, todos os atos ainda eram assinados como "Príncipe Regente", mesmo após a Independência).

Ao contrário do que diz o senso comum, a Independência do Brasil não foi recebida com tranquilidade por Portugal, pelo contrário, travou-se uma guerra em diversas províncias, com destaque para a Bahia (que foi ocupada militarmente por Portugal ${ }^{56}$ e cujo porto foi bloqueado pelo Brasili57), Maranhão (também ocupado pelos portugueses) ${ }^{58}$ o Piauí ${ }^{59}$ e o Pará ${ }^{60}$ (cujos governos permaneceram

BRASIL (Príncipe Regente). Decreto, de 18/09/1822. Dá ao Brasil um escudo de armas. In BRASIL, Collecção das Leis do Império do Brazil de 1822. Parte 2 (Decretos, Cartas e Alvarás), op. cit.

BRASIL (Príncipe Regente). Decreto, de 20/09/1822. Regula os uniformes dos criados da casa do Príncipe Real. In BRASIL, Collecção das Leis do Império do Brazil de 1822. Parte 2 (Decretos, Cartas e Alvarás), op. cit.

55 BRASIL. Ata da Aclamação do senhor D. Pedro, Imperador Constitucional do Brasil, e seu Perpétuo Defensor, em 12/10/1822. In BRASIL, Collecção das Leis do Império do Brazil de 1822. Parte 2 (Decretos, Cartas e Alvarás), op. cit.

56 BRASIL (Príncipe Regente). Proclamação, de 17/06/1822. O Príncipe Regente convida os Povos da Bahia a reconhecerem a sua autoridade. In BRASIL, Collecção das Leis do Império do Brazil de 1822. Parte 2 (Decretos, Cartas e Alvarás), op. cit.

BRASIL (Imperador). Decreto, de 12/11/1822. Manda cobrar direitos das mercadorias estrangeiras reembarcadas da Bahia, durante a ocupação das tropas Portuguesas, e determina que a divida contraída pelo Brigadeiro Ignácio Luiz Madeira de Mello não seja paga pelas rendas da Província. In BRASIL, Collecção das Leis do Império do Brazil de 1822. Parte 2 (Decretos, Cartas e Alvarás), op. cit.

BRASIL (Imperador). Decreto, de 29/11/1822. Manda que, durante a ocupação da Bahia pelas tropas de Portugal, sejam os recursos judiciais interpostos para a Casa de Suplicação desta Corte. In BRASIL, Collecção das Leis do Império do Brazil de 1822. Parte 2 (Decretos, Cartas e Alvarás), op. cit.

BRASIL (Governo do Império). Portaria, de 29/03/1823. Dá instruções ao Comandante em Chefe do Exército Pacificador da Bahia para que de cooperação com a Esquadra Imperial promova a pronta libertação da mesa Província.

57 BRASIL (Imperador). Decreto, de 29/03/1823. Declara em estado de bloqueio o porto da Cidade da Bahia In BRASIL, Collecção das Decisões do Governo do Império do Brazil de 1823, op. cit.

BRASIL (Governo do Império). Portaria, de 30/03/1823. Manda por em rigoroso bloqueio o porto da Bahia e destruir as forças portuguesas. In BRASIL, Collecção das Decisões do Governo do Império do Brazil de 1823, op. cit.

58 BRASIL (Governo do Império). Portaria, de 02/10/1823. Sobre o fato de ter a Província do Maranhão sacudido no dia de 28 de julho deste ano o jugo lusitano e proclamado a Independência do Brasil. In BRASIL, Collecção das Decisões do Governo do Império do Brazil de 1823, op. cit.

59 BRASIL (Governo do Império). Portaria, de 18/12/1822. Censura ao Governo Provisório da Província do Piauí a sua recusa de unir-se à causa do Brasil. In BRASIL, Collecção das Decisões do Governo do Brazil de 1822, op. cit.

BRASIL (Governo do Império). Portaria, de 18/09/1823. Sobre a independência e união do Piaui às mais províncias do Império, e a nomeação de um Governo temporário. In BRASIL, Collecção das Decisões do Governo do Império do Brazil de 1823, op. cit.

60 BRASIL (Governo do Império). Portaria, de 08/04/1823. Censura a recusa da Junta Provisória do Governo Civil da Província do Pará de unir-se à causa do Brasil, e aconselha-a que 
fieis à Portugal) e a Província Cisplatina (de onde a Divisão de Voluntários Reais D'El Rei não havia se retirado) ${ }^{61}$. Por fim, em Portugal, as provincias brasileiras que haviam aderido à Independência do Brasil foram consideradas como rebeldes, tendo cassadas suas representações nas Cortes de Lisboa ${ }^{62}$.

Como represália, o governo brasileiro determinou a expulsão de todos os dissidentes $^{63}$ e proibiu o despacho de embarcações para as províncias ocupadas por tropas portuguesas ${ }^{64}$. Além disso, foram revogados os oficios públicos atribuídos a residentes de Portugal ${ }^{65}$, bem como confiscados os bens dos "vassalos de Portugal"66 (em janeiro de 1823, Dom Pedro I proclamou que todos os brasileiros que não retornassem ao país em seis meses seriam considerados súditos de Portugal e submetidos ao mesmo tratamento ${ }^{67}$, com exceção dos que estivessem estudando na Universidade de Coimbra, que poderiam completar os cursos $\left.^{68}\right)$. Dom Pedro I ainda estabeleceu pesada tributação $(24 \%$, como as demais nações) sobre os gêneros industriais ou manufatureiros portugueses

siga o exemplo dos Governos das mais Províncias. In BRASIL, Collecção das Decisões do Governo do Império do Brazil de 1823, op. cit.

61 BRASIL (Imperador). Carta Imperial, de 28/01/1823. Manda intimar a Divisão Portuguesa existente em Montevidéu que se retire para Portugal, dá várias providências sobre o Estado Cisplatino. In BRASIL, Collecção das Leis do Império do Brazil de 1823. Parte 2 (Decretos, Cartas e Alvarás), op. cit.

BRASIL (Imperador). Proclamação, de 26/05/1823. Incita os Rio-Grandenses do Sul a expelirem de Montevidéu os Portugueses. In BRASIL, Collecção das Leis do Império do Brazil de 1823. Parte 2 (Decretos, Cartas e Alvarás), op. cit.

BRASIL (Imperador). Proclamação, de 26/05/1823. Incita os Paulistas a coadjuvarem no cerco de Montevidéu. In BRASIL, Collecção das Leis do Império do Brazil de 1823. Parte 2 (Decretos, Cartas e Alvarás), op. cit.

62 PORTUGAL (Cortes Gerais). Decreto, de 23/01/1823. Declarar rebeldes todas as Provincias do Brasil que espontânea e livremente desobedecerem á Constituição e Leis da Monarquia Portuguesa. In PORTUGAL, Legislação Régia (Digitalização da Colecção de Legislação Portuguesa desde 1603 a 1910), op. cit.

63 BRASIL (Governo do Império). Portaria, de 06/11/1822. Manda retirar para fora desta Capital todos os indivíduos considerados pela opinião pública como hostis ao Governo. In BRASIL, Collecção das Decisões do Governo do Império do Brazil de 1823, op. cit.

64 BRASIL (Governo do Império). Portaria, de 05/12/1822. Explica a Portaria que manda proibir o despacho de embarcações para portos do Império em que há Tropas Portuguesas. In BRASIL, Collecção das Decisões do Governo do Império do Brazil de 1823, op. cit.

65 BRASIL (Imperador). Decreto, de 12/11/1822. Declara de nenhum efeito as graças e ofícios pertencentes a pessoas residentes em Portugal. In BRASIL, Collecção das Leis do Império do Brazil de 1822. Parte 2 (Decretos, Cartas e Alvarás), op. cit.

66 BRASIL (Imperador). Decreto, de 11/12/1822. Manda sequestrar as mercadores, prédios e bens pertencentes a vassalos de Portugal. In BRASIL, Collecção das Leis do Império do Brazil de 1822. Parte 2 (Decretos, Cartas e Alvarás), op. cit.

67 BRASIL (Imperador). Proclamação, de 08/01/1823. Convida os brasileiros residentes fora da pátria para voltarem a ela dentro de seis meses. In BRASIL, Collecção das Leis do Império do Brazil de 1823. Parte 2 (Decretos, Cartas e Alvarás), op. cit.

68 BRASIL (Imperador). Decreto, de 18/02/1823. Declara que os brasileiros que estiverem estudando na Universidade de Coimbra não estão compreendidos na proclamação de 8 de janeiro último. In, BRASIL, Collecção das Leis do Império do Brazil de 1823. Parte 2 (Decretos, Cartas e Alvarás), op. cit. 
(enquanto os equivalentes ingleses eram submetidos a tributos de $15 \%)^{69}$ e concedeu Patentes de Corso, autorizando a pirataria contra o "pavilhão português"70.

Apesar de tais medidas, Dom Pedro I concedeu anistia para todos que aderissem à causa brasileira, inclusive portugueses e estrangeiros ${ }^{71}$, e ofereceu cidadania brasileira a todo súdito de Portugal que decidisse residir no Brasil, desde que jurasse fidelidade ao Imperador ${ }^{72}$ (posteriormente, esta prerrogativa foi suspensa ${ }^{73}$ e os portugueses que não prestaram juramento foram expulsos em 182474). Além disso, o governo brasileiro mandou proibir distinções de nascimento entre brasileiros e portugueses ${ }^{75}$.

A guerra duraria até 02 de julho de 1823 na Bahia76 e 28 de julho de 1823 no Maranhão77. Os escravos que lutaram foram libertos (mediante indenização aos proprietários) ${ }^{78}$. Somente em 29 de agosto de 1825 Portugal reconheceria

69 BRASIL (Imperador). Decreto, de 30/12/1822. Manda sujeitar os gêneros de indústria e manufatura portuguesa ao pagamento de direitos de 24\% de importação; admite a despacho o rapé estrangeiro; e estabelece taxas fixas para os gêneros denominados molhados. In, BRASIL, Collecção das Leis do Império do Brazil de 1822. Parte 2 (Decretos, Cartas e Alvarás), op. cit.

70 BRASIL (Imperador). Alvará, de 30/12/1822. Concede aos súditos deste Império e estrangeiros a faculdade de armarem corsários que se empreguem contra as propriedades e pavilhão português. In, BRASIL, Collecção das Leis do Império do Brazil de 1822. Parte 2 (Decretos, Cartas e Alvarás), op. cit.

71 BRASIL (Príncipe Regente). Decreto, de 18/09/1822. Concede anistia geral para as passadas opiniões políticas; ordena o distintivo - Independência ou Morte - e a saida dos dissidentes. In, BRASIL, Collecção das Leis do Império do Brazil de 1822. Parte 2 (Decretos, Cartas e Alvarás), op. cit.

72 BRASIL (Imperador). Decreto, de 14/01/1823. Sobre as condições que podem ser admitidos no Brasil os súditos de Portugal. In, BRASIL, Collecção das Leis do Império do Brazil de 1823. Parte 2 (Decretos, Cartas e Alvarás), op. cit.

73 BRASIL (Imperador). Decreto, de 20/11/1823. Suspende o Decreto de 14 de janeiro deste ano que concedeu os foros de cidadão brasileiro aos portugueses que vierem residir no Império. In BRASIL, Collecção das Leis do Império do Brazil de 1823. Parte 2 (Decretos, Cartas e Alvarás), op. cit.

74 BRASIL (Governo do Império). Portaria, de 03/01/1824. Manda sair do Império os Portugueses que não tiverem prestado juramento de fidelidade à causa do Brasil. In BRASIL, Collecção das Decisões do Governo do Império do Brazil de 1824, Rio de Janeiro, Imprensa Nacional, 1886. Disponivel em

http://www2.camara.leg.br/atividade-legislativa/legislacao/publicacoes/doimperio. Acesso em 09/01/2018.

75 BRASIL (Governo do Império). Portaria, de 16/07/1823. Manda proibir a distinção de nascimento entre brasileiros e portugueses. In BRASIL, Collecção das Decisões do Governo do Império do Brazil de 1823, op. cit.

76 BRASIL (Governo do Império). Portaria, de 23/07/1823. Congratula-se com o Governo Provisório da Bahia pela evacuação das tropas portuguesas e providências sobre o bem público da Provincia. In BRASIL, Collecção das Decisões do Governo do Império do Brazil de 1823, op. cit.

77 BRASIL (Governo do Império). Portaria, de 02/10/1823. Sobre o fato de ter a Província do Maranhão sacudido no dia de 28 de julho deste ano o jugo lusitano e proclamado a Independência do Brasil. In BRASIL, Collecção das Decisões do Governo do Império do Brazil de 1823, op. cit.

78 BRASIL (Governo do Império). Portaria, de 30/07/1823. Manda libertar os escravos que serviram nas fileiras do exercido brasileiro contra as tropas portuguesas, na luta da 
formalmente a Independência do Brasil, por meio do Tratado de Paz e Aliança (antes disso, ainda em junho de 1824, correram rumores de expedições militares que seriam enviadas de Portugal para reconquistar o Brasil) ${ }^{79}$.

\section{A ASSEMBLEIA GERAL CONSTITUINTE E LEGISLATIVA}

Uma vez independente, o Brasil passou a tratar da elaboração de sua própria Constituição. Após cinco sessões preparatórias, em 03 de maio de 1823 , a Assembleia Geral Constituinte e Legislativa reuniu-se em sessão inaugural para elaborar uma Constituição digna do Brasil e do Imperador, conforme suas próprias palavras na "Fala do Trono" 80. Vale lembrar que a Assembleia foi convocada em 03 de junho de1822, antes mesmo da declaração de Independência (07/09/1822), e que se reuniu antes do final da guerra (julho de 1823). Em seu discurso na sessão de abertura ("Fala do Trono"), Dom Pedro I manifestou que esperava "uma constituição em que os três poderes sejam bem divididos", mas que desse "toda a força necessária ao poder executivo", e que, se assim fosse, a constituição receberia sua "imperial aceitação".

Apesar de terem sido estabelecidas 100 vagas para constituintes ${ }^{81}$, somente foram ocupadas 89 cadeiras $^{82}$. Uma comissão de sete constituintes ${ }^{83}$ liderados $^{2}$ por Antônio Carlos Ribeiro de Andrada Machado e Silva ("Ribeiro de Andrada"), irmão de José Bonifácio, elaborou um projeto de Constituição. Ao ser enviado a Dom Pedro I, o Imperador teria manifestado que "recebeu com especial agrado o

independência, na Provincia da Bahia. In BRASIL, Collecção das Decisões do Governo do Império do Brazil de 1823, op. cit.

79 BRASIL (Imperador). Proclamação, de 10/06/1824. Sobre a expulsão das tropas lusitanas para fora do Império. In BRASIL, Collecção das Leis do Império do Brazil de 1824. Parte 2 (Decretos, Cartas e Alvarás), Rio de Janeiro, Imprensa Nacional, 1886. Disponível em http://www2.camara.leg.br/atividade-legislativa/legislacao/publicacoes/doimperio. Acesso em $09 / 01 / 2018$.

BRASIL (Imperador). Proclamação, de 10/06/1824. Sobre a expedição que se preparar em Portugal para invadir o nosso país. In BRASIL, Collecção das Leis do Império do Brazil de 1824. Parte 2 (Decretos, Cartas e Alvarás), op. cit.

BRASIL (Governo do Império). Portaria, de 11/06/1824. Dá providências para prevenir a invasão portuguesa nas Províncias. In BRASIL, Collecção das Decisões do Governo do Império do Brazil de 1824, op. cit.

80 BRASIL (Imperador). Fala com que Sua Majestade o Imperador abriu a Assembleia Geral Legislativa e Constituinte no dia 3 de maio de 1823. In BRASIL, Collecção das Leis do Império do Brazil de 1823. Parte 2 (Decretos, Cartas e Alvarás), op. cit.

81 BRASIL (Governo). Portaria, de 19/06/1822. Instruções a que se refere o Real Decreto de 3 de junho do corrente ano que manda convocar uma Assembleia Geral Constituinte e Legislativa para o Reino do Brasil. In BRASIL, Collecção das Decisões do Governo do Brazil de 1822, op. cit.

82 BRASIL (Câmara dos Deputados), Inventário analitico do arquivo da Assembleia Geral Constituinte e Legislativa do Império do Brasil, 1823, 2. ed., rev. e reform, Brasília, Câmara dos Deputados, Edições Câmara, 2015.

83Antônio Carlos Ribeiro de Andrada Machado e Silva, José Bonifácio de Andrada e Silva, Antônio Luís Pereira da Cunha, Manoel Ferreira da Câmara Bithencourt e Sá, Pedro de Araújo Lima, José Ricardo da Costa Aguiar de Andrada e Francisco Muniz Tavares. Cf. Jose Afonso da SILVA, O Constitucionalismo Brasileiro: (evolução institucional), São Paulo: Malheiros, 2011. 
exemplar do projeto da Constituição para o Império do Brasil que a Assembleia Geral Constituinte e Legislativa resolveu fazer chegar ao seu conhecimento"84.

O Projeto de Constituição de Ribeiro de Andrada previa uma monarquia constitucional, com voto censitário (calculado com base em alqueires de mandioca, cf. arts. 123, 126 e 129) e tripartição equilibrada dos poderes. Ao Imperador era atribuído apenas o Poder Executivo (art. 138), cabendo-lhe apenas o veto suspensivo aos projetos do Poder Legislativo (art. 113) e não detinha poderes para dissolver a Câmara (art. 54). O Imperador somente poderia aceitar coroa estrangeira (como a de Portugal, por exemplo), se renunciasse ao Trono Brasileiro (art. 157). As forças armadas ficariam sob as ordens do Executivo (art. 227), mas somente poderiam ser utilizadas dentro do território nacional mediante autorização do Parlamento (art. 230, 231 e 232). ${ }^{85}$

O Projeto Ribeiro de Andrada foi apresentado à Assembleia Geral Constituinte e Legislativa em $1^{\circ}$ de setembro de 1823 e teve sua discussão iniciada a 15 do mesmo mês ${ }^{86}$. Além da elaboração da Constituição, a Assembleia Geral Constituinte e Legislativa também se dedicou à tarefa de legislar ${ }^{87}$ : extinguiu o Conselho de Procuradores das Províncias ${ }^{88}$, organizou e estabeleceu a vigência da legislação promulgada durante o período de dualidade e sobreposição de sistemas ${ }^{89}$ (decorrentes da disputa entre Dom Pedro e as Cortes de Lisboa, entre 25/04/1821 e 07/09/1822); e deu nova forma aos governos das províncias $^{90}$, vedou aos deputados que exercessem outros empregos ${ }^{91}$ e proibiu as sociedades secretas ${ }^{92}$.

84 Francisco Inácio Marcondes HOMEM DE MELO, A Constituinte perante a Historia, Brasília, DF, Senado Federal, 1996.

85 BRASIL (Assembleia Geral Constituinte e Legislativa), Projeto de Constituição apresentado pela Comissão da Constituição, de 1\%09/1823. Disponivel em

https://arquivohistorico.camara.leg.br/index.php/projeto-de-constituicao-apresentado-pelacommissao-de-constituicao. Acesso em 13/01/2018.

86 Francisco Inácio Marcondes HOMEM DE MELO, A Constituinte perante a Historia, op. cit.

87 BRASIL (ASSEMBLEIA GERAL). Lei, de 20/10/1823. Estabelece provisoriamente a forma que deve ser observada na promulgação dos decretos da Assembleia Geral Constituinte e Legislativa do Brasil. In BRASIL, Collecção das Leis do Império do Brazil de 1823. Parte 1 (Leis da Assembléa Geral Constituinte e Legislativa), Rio de Janeiro, Imprensa Nacional, 1887. Disponivel em http://www2.camara.leg.br/atividade-legislativa/legislacao/publicacoes/doimperio. Acesso em 09/01/2018.

88 BRASIL (ASSEMBLEIA GERAL). Lei, de 20/10/1823. Revoga o Decreto de 16 de fevereiro de 1822 que criou o Conselho de Procuradores de Província. In BRASIL, Collecção das Leis do Império do Brazil de 1823. Parte 1 (Leis da Assembléa Geral Constituinte e Legislativa), op. cit.

89 BRASIL (ASSEMBLEIA GERAL). Lei, de 20/10/1823. Declara em vigor a legislação pela qual se regia o Brasil até 25 de abril de 1821 e bem assim as leis promulgadas pelo Senhor D. Pedro, como Regente e Imperador daquela data em diante, e os decretos das Cortes Portuguesas que são especificados. In BRASIL, Collecção das Leis do Império do Brazil de 1823. Parte 1 (Leis da Assembléa Geral Constituinte e Legislativa), op. cit.

90 BRASIL (ASSEMBLEIA GERAL). Lei, de 20/10/1823. Dá nova forma aos Governos das Provincias, criando para cada uma delas um Presidente e Conselho. In BRASIL, Collecção das Leis do Império do Brazil de 1823. Parte 1 (Leis da Assembléa Geral Constituinte e Legislativa), op. cit.

91 BRASIL (ASSEMBLEIA GERAL). Lei, de 20/10/1823. Proíbe que os Deputados à Assembleia Geral Constituinte exerçam outro emprego durante a sua Deputação, e que peçam e aceitem para 
Durante os trabalhos da Constituinte algumas criticas ao Imperador começaram a se manifestar. A "Fala do Trono" proferida por Dom Pedro I na sessão inaugural foi questionada por alguns deputados nas sessões seguintes, e defendida por outros, sendo que, curiosamente, a posição mediadora coube a Ribeiro de Andrada (há quem diga, inclusive, que a "Fala do Trono" havia sido escrita por seu irmão, José Bonifácio) ${ }^{93}$. Apesar disso, aos poucos a relação entre Dom Pedro I e os irmãos Andrada foi gradualmente se deteriorando até que, em 17 de julho de 1823, o gabinete de José Bonifácio foi demitido e outro nomeado em seu lugar (com elementos mais favoráveis ao "partido de Portugal")94. Uma vez na oposição, os irmãos Andrada passaram a apoiar o grupo de constituintes que criticava abertamente o novo governo, especialmente por parte dos jornais " $\mathrm{O}$ Tamoyo" e "Sentinela de Praia Grande"95. Um dos principais atos de afronta da Assembleia à autoridade do Imperador foi a lei que regulamentava a promulgação da legislação aprovada pela Assembleia Geral Constituinte e Legislativa, que dispensava a sanção imperial ${ }^{96}$.

O novo gabinete, abertamente pró-Portugal, aprovou a incorporação dos prisioneiros portugueses nas forças armadas brasileiras, o que logo causou um incidente: em 06 de novembro de 1823, dois soldados portugueses agrediram um cidadão brasileiro que eles entenderam ser o autor (sob o pseudônimo de "Brasileiro Resoluto") de textos contra Portugal97. A Assembleia Geral Constituinte e Legislativa assumiu a defesa do cidadão agredido e passou a questionar o governo e exigir que tomasse providência com relação aos soldados portugueses recém-incorporados às tropas ${ }^{98}$. Por sua vez, as tropas reivindicaram ao Imperador que coibisse a Liberdade de Imprensa e expulsasse os irmãos Andrada da Assembleia, gerando grande agitação no Rio de Janeiro na noite do dia 10 de novembro de $1823^{99}$.

Diante das movimentações militares, em 11 de novembro de 1823, a Assembleia Geral Constituinte e Legislativa decidiu manter-se em sessão permanente ("Noite da Agonia")100, mas no dia seguinte o Imperador junto com

si ou para outrem qualquer graça de emprego. In BRASIL, Collecção das Leis do Império do Brazil de 1823. Parte 1 (Leis da Assembléa Geral Constituinte e Legislativa), op. cit.

92 BRASIL (ASSEMBLEIA GERAL). Lei, de 20/10/1823. Revoga o Alvará de 30 de março de 1818 sobre Sociedades Secretas. In BRASIL, Collecção das Leis do Império do Brazil de 1823. Parte 1 (Leis da Assembléa Geral Constituinte e Legislativa), op. cit.

93 Paulo BONAVIDES e Paes de ANDRADE, Historia Constitucional do Brasil, Brasília, OAB, 2002.

94 Francisco Inácio Marcondes HOMEM DE MELO, A Constituinte perante a Historia, op. cit.

95 Francisco Inácio Marcondes HOMEM DE MELO, A Constituinte perante a Historia, op. cit.

96 BRASIL (ASSEMBLEIA GERAL). Lei, de 20/10/1823. Estabelece provisoriamente a forma que deve ser observada na promulgação dos decretos da Assembleia Geral Constituinte e Legislativa do Brasil. In, BRASIL, Collecção das Leis do Império do Brazil de 1823. Parte 1 (Leis da Assembléa Geral Constituinte e Legislativa), op. cit.

97 Paulo BONAVIDES e Paes de ANDRADE, Historia Constitucional do Brasil, op. cit.

98 Paulo BONAVIDES e Paes de ANDRADE, Historia Constitucional do Brasil, op. cit.

99 Francisco Inácio Marcondes HOMEM DE MELO, A Constituinte perante a Historia, op. cit.

100 Francisco Inácio Marcondes HOMEM DE MELO, A Constituinte perante a Historia, op. cit. 
suas tropas cercou o prédio da Assembleia101 e decretou a dissolução da Constituinte $^{102}$. Foram presos os deputados José Bonifácio de Andrada e Silva, Antônio Carlos Ribeiro de Andrada Machado e Silva, Martim Francisco Ribeiro de Andrada, José Joaquim da Rocha, Francisco Jê Acaiaba de Montezuma (futuro Visconde de Jequitinhonha), Belchior Pinheiro de Oliveira e Nicolau Pereira de Campos Vergueiro. Com exceção de Vergueiro, todos foram expulsos do Brasil em 15 de novembro de $1823^{103}$.

Dom Pedro I declarou que convocaria uma nova Assembleia Constituinte ${ }^{104}$, que seria "duplicadamente mais liberal", mas esta nunca se reuniu. O Imperador preferiu criar um Conselho de Estado105 para tratar dos "negócios de maior monta", sendo este composto por 10 membros, incluindo os seis Ministros de Estado (José Severiano Maciel da Costa, Luiz José de Carvalho e Melo, Clemente Ferreira França, Mariano José Pereira da Fonseca, João Gomes da Silveira Mendonça, Francisco Vilela Barbosa, Barão de Santo Amaro, Antônio Luiz Pereira da Cunha, Manuel Jacinto Nogueira da Gama e José Joaquim Carneiro de Campos) ${ }^{106}$. O Conselho de Estado elaborou um novo projeto de Constituição, conforme orientações dadas pelo Imperador. A nova proposta de Constituição provavelmente foi redigida por José Joaquim Carneiro de Campos, futuro Marques de Caravela, e é inspirado no anteprojeto de Ribeiro de Andrada, porém com algumas melhorias de natureza técnica (linguagem jurídica, organização etc) e pioras de natureza política (com destaque para o Poder Moderador) ${ }^{107}$.

Apesar de inspirado no Projeto Ribeiro de Andrada, o Poder Moderador previsto na nova proposta de Constituição dava poderes quase absolutos ao Imperador, entre eles, o de nomear senadores (arts. 43 e 101, I), dissolver a Câmara dos Deputados (art. 101, V), nomear magistrados (art. 102, III) e suspendê-los (arts. 101, VII, e 154). Isso sem se falar que o Imperador também era titular do Poder Executivo. Em suma, era uma Constituição "liberal em matéria de direitos individuais, mas centralizadora e autoritária na soma de poderes que concedia ao monarca constitucional"108.

O novo projeto foi submetido à apreciação das câmaras, pois "uma nova Assembleia Geral, Constituinte, e Legislativa nada mais poderia fazer do que aceitar este projeto, ou discutindo-o fazer outro no mesmo sentido, mas por

101 Paulo BONAVIDES e Paes de ANDRADE, Historia Constitucional do Brasil, op. cit.

102 BRASIL (Imperador). Decreto, de 12/11/1823. Dissolve a Assembleia Geral Legislativa e Constituinte e convoca outra. In BRASIL, Collecção das Leis do Império do Brazil de 1823 . Parte 2 (Decretos, Cartas e Alvarás), op. cit.

103 Paulo BONAVIDES e Paes de ANDRADE, Historia Constitucional do Brasil, op. cit.

104 BRASIL (Imperador). Decreto, de 17/11/1823. Manda proceder as eleições para Deputados à Assembleia Geral Constituinte e Legislativa. In BRASIL, Collecção das Leis do Império do Brazil de 1823. Parte 2 (Decretos, Cartas e Alvarás), op. cit.

105 BRASIL (Imperador). Decreto, de 13/11/1823. Explica a expressão - perjura -, empregada no Decreto de 12 do corrente em relação à Assembleia Geral Constituinte e Legislativa. In BRASIL, Collecção das Leis do Império do Brazil de 1823. Parte 2 (Decretos, Cartas e Alvarás), op. cit.

106 Paulo BONAVIDES e Paes de ANDRADE, Historia Constitucional do Brasil, op. cit.

107 Paulo BONAVIDES e Paes de ANDRADE, Historia Constitucional do Brasil, op. cit.

108 Paulo BONAVIDES e Paes de ANDRADE, Historia Constitucional do Brasil, op. cit. 
outras palavras, o que levaria pelo menos dois anos, e nesse tempo ocorreria risco a nossa segurança pública, pois poderia aparecer a anarquia, o maior flagelo do mundo, além de que as outras Nações, não nos achando constituídos, estariam em observação, e não reconheceriam (como muito convém) a nossa Independência, mui necessário este reconhecimento para consolidar esse rico fértil e vasto império" (sic) ${ }^{109}$.

Em 25 de março de 1824, Dom Pedro I, Imperador Constitucional e Defensor Perpétuo do Brasil, após aprovação por parte das câmaras ${ }^{110}$ (ao contrário do texto do decreto, a aprovação não foi unânime, com destaque para a Câmara de Itu, liderada pelo futuro regente Diogo Antônio Feijó) ${ }^{111}$, mandou jurar a Constituição Política do Império do Brasil112. Uma vez que já havia uma Constituição, o Imperador decretou que se procedesse a eleição de deputados e senadores para uma "Assembleia simplesmente Legislativa"113.

Desta forma concluiu-se o $1^{\circ}$ Período Constituinte do Brasil (período transitório durante o qual se elabora uma Constituição) e inaugurou-se o $1^{\text {a }}$ Período Constitucional, que duraria até a Proclamação da República em 15 de novembro de 1889.

A partir da outorga da Constituição Politica do Império do Brasil encerra-se o objeto deste artigo, mas não se encerram as tensões entre Dom Pedro I e seus adversários (por exemplo, como imediata reação à nova Constituição, eclodiu em Pernambuco, rapidamente alastrando-se pelo Ceará, Paraíba e Rio Grande do Norte, o movimento republicado e separatista que viria a culminar na "Confederação do Equador") ${ }^{114}$. Em 07 de abril de 1831, durante uma grave crise política, o Imperador do Brasil foi obrigado a abdicar do Trono Brasileiro ${ }^{115}$ e retornou a Portugal, onde foi enfrentar seu irmão, Dom Miguel, que havia

109 BRASIL (Governo do Império). Portaria, de 17/12/1823. Remete às Câmaras o Projeto de Constituição. In BRASIL, Collecção das Decisões do Governo do Império do Brazil de 1823, op. cit.

110 BRASIL (Imperador). Decreto, de 11/03/1824. Manda jurar o projeto da Constituição Política do Império, e designa para esta solenidade o dia 25 do corrente mês. In BRASIL, Collecção das Leis do Império do Brazil de 1824. Parte 2 (Decretos, Cartas e Alvarás), op. cit.

111 Paulo BONAVIDES e Paes de ANDRADE, Historia Constitucional do Brasil, op. cit.

112 BRASIL (Imperador). Carta de Lei, de 25/03/1824. Manda observar a Constituição Política do Império, oferecida e jurada por Sua Majestade o Imperador. In BRASIL, Collecção das Leis do Império do Brazil de 1824. Parte 1 (Constituição Politica do Império do Brazil), Rio de Janeiro, Imprensa Nacional, 1886. Disponivel em http://www2.camara.leg.br/atividadelegislativa/legislacao/publicacoes/doimperio. Acesso em 09/01/2018.

113 BRASIL (Imperador). Decreto, de 26/03/1824. Manda proceder à eleição dos Deputados e Senadores da Assembleia Geral Legislativa e dos Membros dos Conselhos Gerais das Províncias. In BRASIL, Collecção das Leis do Império do Brazil de 1824. Parte 2 (Decretos, Cartas e Alvarás), op. cit.

114 Jose Afonso da SILVA, O Constitucionalismo Brasileiro: (evolução institucional), op. cit.

115 BRASIL (Senado). Ato de Abdicação de Sua Majestade, o senhor D. Pedro I. Eleição da regência Provisória, de 07/04/1831. In BRASIL, Collecção das Leis do Império do Brazil de 1831. Segunda parte (Atos do Poder Executivo), Rio de Janeiro, Imprensa Nacional, 1875. Disponivel em http://www2.camara.leg.br/atividade-legislativa/legislacao/publicacoes/doimperio. Acesso em $09 / 01 / 2018$. 
usurpado o trono de sua filha, Dona Maria II (com quem Dom Miguel fora casado entre 1826 e 1834, quando o casamento foi anulado).

Feita a Independência do Brasil, a História Constitucional Brasileira se afasta da de Portugal. No Brasil, a Constituição Imperial (que consolidaria o processo independentista) foi a de mais longa duração no país (65 anos de vigência, entre 1824 e 1889, até a Proclamação da República). Por outro lado, a Constituição Portuguesa de 1822 teve curta duração, tendo sido "suspensa" pelo Rei Dom João VI de Portugal já em 3 de junho de 1823 (durou menos de um ano), vindo novamente a vigorar entre 10 de setembro de 1836 e 20 de março de 1838 . Curiosamente, a Constituição com maior duração na História de Portugal (72 anos, em três períodos distintos) foi a Carta Constitucional Portuguesa de 1826, também outorgada por Dom Pedro I, no curto período em que assumiu o trono de Portugal como Dom Pedro IV (reinou por menos de dois meses e abdicou em favor da filha, Dona Maria II).

\section{CONCLUSÃo}

Sendo assim, pode-se dizer que o primeiro documento constitucional a vigorar no Brasil foi as "Bases para a Constituição da Monarquia Portuguesa", documento este que foi jurado pelo Rei de Portugal e aplicado no Brasil $(18 / 02 / 1821)$ antes mesmo de ter sido aprovado pelas Cortes de Lisboa (10/03/1821) e que continuou em vigor mesmo após a Independência do Brasil (7/09/1822), sendo apenas substituído pela Constituição do Império (25/03/1824). Ou seja, o documento "Bases para a Constituição" vigorou por mais tempo no Brasil do que em Portugal (onde foi substituído em 23/09/1822 pela $1^{\text {a }}$ Constituição Portuguesa).

Também é possivel afirmar que, durante um único dia (21/04/1821), o Brasil foi regido pela Constituição Espanhola de Cádiz. Seria a primeira Constituição a vigorar no Brasil, uma vez que as "Bases", apesar da natureza constitucional, não configuram uma Constituição de fato.

Resumindo, foram três os documentos que iniciaram a vida constitucional brasileira:

- Bases da Monarquia: de 18/02/1821 até 20/04/1821 ( $1^{\circ}$ período); e de 22/04/1821 até 24/03/1824 ( $2^{\circ}$ período);

- Constituição Espanhola de Cádiz: 21/04/1821; e

- Constituição Imperial: de 24/03/1824 até 15/11/1889

Com relação à dualidade de poderes, algumas datas merecem atenção especial, pois elas demarcam com razoável exatidão cada um dos pontos críticos:

- 25 de abril de 1821 (retorno de Dom João VI para Portugal): Enquanto esteve no Brasil, Dom João VI não enfrentou as Cortes de Lisboa, ou seja, não houve dualidade de poderes (posteriormente, em Portugal, havia tal enfrentamento, mas após a Independência do Brasil). Além disso, até aquela data, o governo de Brasil e Portugal era indivisivel, ou seja, se houvesse dualidade (e não houve), teria sido uma disputa no interior do Estado Português. No entanto, com o retorno de Dom João VI para Portugal, o governo do Brasil passa a ser exercido pelo Príncipe Regente que inicialmente manteve boas 
relações com as Cortes, mas que logo se tornaram divergentes. Dia 25 de abril de 1821 é a melhor data para identificar o início da dualidade de poderes.

- 09 de janeiro de 1822 (Dia do Fico): O Príncipe Regente e as Cortes Portuguesas não concordavam sobre a forma como o Brasil deveria ser governado. O estremecimento de relações chegou ao ponto das Cortes determinarem que Dom Pedro se retirasse do território nacional, o que ele recusou-se a fazer. A partir de então, a dualidade deixa de ser velada e torna-se evidente.

- 07 de setembro de 1822 (Independência do Brasil): A partir do Dia do Fico, a disputa entre as Cortes e o Príncipe é direta. Dom Pedro invalida atos jurídicos das Cortes, e as Cortes invalidam atos jurídicos do Príncipe Regente. Não há mais possibilidade de conciliação jurídica. A ruptura de fato foi formalizada com o "Grito do Ipiranga", mas Brasil e Portugal já estavam em guerra e assim continuariam. A dualidade entre Dom Pedro e as Cortes de Lisboa se encerra com vitória do Príncipe Regente.

- 03 de maio de 1823 (Sessão Inaugural da Assembleia Geral Constituinte e Legislativa): Da Independência até a instalação oficial da Assembleia Geral Constituinte e Legislativa, Dom Pedro I governou sozinho e absoluto, pois não havia instituições para dar corpo às "Bases da Constituição Política da Monarquia", que ele jurou e nunca rejeitou. Ao ser estabelecido um novo Poder (a Assembleia Geral Constituinte e Legislativa), surgiu novo processo de dualidade, pois o Imperador não pretendia submeter-se. Assim como ocorreu na disputa com as Cortes Portuguesas, a relação entre o Imperador e a Assembleia Geral Constituinte e Legislativa se iniciou de maneira cordial, mas gradualmente passaram à disputa.

- 12 de novembro de 1823 (Dissolução da Assembleia Geral Constituinte e Legislativa): A Assembleia Geral Constituinte e Legislativa se considerava tão representante da Nação quanto o Imperador, de modo a não haver hierarquia com relação ao monarca. Apesar da cordialidade dos primeiros dias, a dualidade de poderes já se fazia presente desde a instalação da Assembleia. Novamente a história se repete e a disputa entre Dom Pedro I e a Assembleia Geral Constituinte e Legislativa foi se intensificando até o momento da ruptura. O Imperador, com tropas militares, dissolve a Assembleia. Esta data poderia ser o auge do segundo processo de dualidade caso houvesse alguma resistência por parte da Assembleia, pois a dualidade deixaria de ser dissimulada e não haveria mais possibilidade de conciliação jurídica. A resistência não ocorreu e a Assembleia resignou-se a acatar sua dissolução determinada por outro Poder.

- 25 de março de 1824 (Outorga da Constituição Imperial): Finalizamos com a data da outorga da Constituição Imperial sob o aspecto meramente formal, pois Dom Pedro I governou com poderes absolutos mesmo havendo uma Constituição. A primeira legislatura da Assembleia Geral Legislativa (titular do Poder Legislativo) só foi reunir-se em 1826 e nunca conseguiu se impor ao Imperador. A normalidade constitucional só surgiu de fato com a renúncia de Dom Pedro I em 07 de abril de $1831^{116}$.

116 Paulo BONAVIDES e Paes de ANDRADE, Historia Constitucional do Brasil, op. cit. 
Encerramos com uma reflexão: Por um lado, a primeira dualidade (Príncipe Regente vs. Cortes Portuguesas) é um elemento essencial da Independência do Brasil. Tal disputa é um dos elementos fundadores do Brasil constitucional. Por outro lado, a segunda dualidade (Imperador vs. Assembleia Geral Constituinte e Legislativa) revela a primeira falha da História Constitucional Brasileira, pois, sempre que o Poder Executivo foi contestado pelos demais, ele se impôs pela força das armas. A crise da segunda dualidade viria a se repetir muitas vezes na História do Brasil, quase sempre seguida por ruptura da ordem institucional e outorga de uma Constituição autoritária.

Enviado el (Submission Date): 02/03/2018

Aceptado el (Acceptance Date): 16/04/2018 